\title{
Reactive Power of Asynchronous Electric Drives with Semiconductor Converters
}

\author{
Yuliia Kovalova $^{1}$ (D), Victor Kovalov ${ }^{2}$ (D) , and Irina Shcherbak ${ }^{1}$ \\ 1 O. M. Beketov National University of Urban Economy in Kharkiv, Kharkiv, Ukraine \\ 2 National Technical University “Kharkiv Polytechnic Institute", Kharkiv, Ukraine
}

\author{
Article History \\ Received: \\ 18 March 2021 \\ Accepted: \\ 25 April 2021 \\ Published online: \\ 30 April 2021 \\ Keywords \\ Induction motor; \\ Semiconductor \\ Converter; \\ Reactive Power
}

\begin{abstract}
The purpose of the article is to obtain a ratio for determining the reactive power of induction motors when powered by semiconductor converters. The task is to determine the dependence of reactive power on control parameters of the converters. The research method used is computer simulation of electric drive based on Fryze power theory for non-sinusoidal currents. The result is the obtained expression for the calculation of reactive power, which takes into account the rated idle current of the motor with sinusoidal power supply and the type of converter, due to introducing special coefficients. Numerical values of the latter, depending on the control parameter, are obtained on computer models with their subsequent approximation. The scientific novelty of the research is in the further development of Fryze power theory in the direction of decomposition of non-sinusoidal current components using computer models. The practical significance is the obtained expression for determining the reactive power of an asynchronous electric drive with a thyristor voltage converter, on the basis of which the capacity of compensating capacitors is calculated to increase its energy efficiency.
\end{abstract}

\section{INTRODUCTION}

Asynchronous motors with thyristor, triac and transistor power converters can be used to regulate the speed of turbomechanisms, such as pumps for pumping water to the upper floors of high-rise buildings. Frequency converters can also be used, but, compared to voltage converters, their price is 22.5 times higher and they are significantly more difficult to operate.

The control of pump speed at variable demand for water allows to reduce losses of the electric power up to $30 \%$. The second stage of reducing power losses is to compensate for reactive power using capacitors, but to select them, it is necessary to develop a method for calculating the reactive power of an induction motor depending on the control parameter of the semiconductor converter. Therefore, the task of compiling such a technique is relevant.

It is obvious that in the case of non-sinusoidal power supply of an induction motor, the reactive power can be determined only by computer simulation. Before modeling, it is necessary to consider theories of reactive power for non-sinusoidal condi- tions, the general analysis of which was carried out in [1-3].

Budeanu power theory is based on the decomposition of non-sinusoidal voltage and current into harmonic components, with reactive power equal to

$$
Q=\sum_{k=1}^{13}\left(U_{s k} I_{s k} \sin \phi_{k}\right)=j \sum_{k=1}^{13}\left(I_{s k}^{2} X_{s k}\right),
$$

where $U_{s k}$ is the effective value of the $k$ th harmonic of the stator voltage; $I_{s k}$ is the effective value of the $k$ th harmonic of the stator current; $\phi_{k}$ is the shift angle between the harmonics of voltage and current; $X_{s k}=\omega_{s k} \cdot L_{s}$ is the inductive resistance of the stator winding for the $k$ th harmonics. Budeanu theory was further developed, for example, in [4-11]. In particular, in $[12,13]$ this theory was used for the case of a single-phase voltage converter.

Fryze power theory is based on the decomposition of non-sinusoidal current into active and reactive components. The values of the current components are determined on the basis of the thermal action of the non-sinusoidal current, i.e., the heat generated in the power circuit by the total current is equal to the sum of the heat from its components.

Corresponding author: kovalova.jv@gmail.com (Yuliia Kovalova)

(C) 2021 The Author(s). Published by O. M. Beketov National University of Urban Economy in Kharkiv Use permitted under Creative Commons Attribution 4.0 International (CC BY 4.0)

Cite as: Kovalova, Y., Kovalov, V., \& Shcherbak, I. (2021). Reactive power of asynchronous electric drives with semiconductor converters. Lighting Engineering \& Power Engineering, 60(1), 9-14. https:/ / doi.org/10.33042/2079-424X.2021.60.1.02 
Since heat is proportional to the square of the current, the square of the effective value of the total current is equal to $I_{t}^{2}=I_{a}^{2}+I_{r}^{2}$, where $I_{a}, I_{r}$ are effective current values of active and reactive components of non-sinusoidal current. Then the reactive power of the motor, with consideration to its equivalent circuit, is equal to

$Q_{L}=\left(x_{0}+x_{\sigma}\right) I_{r}^{2}$,

where $x_{0}, x_{\sigma}$ are values of inductive resistance to magnetization and dissipation in the equivalent circuit of an induction motor, which are specified in reference books or in technical data sheets for motors.

From the analysis of the theories, it follows that the calculation of reactive power in terms of time, in comparison with Budeanu theory, it is advisable to carry out using Fryze power theory, which is obvious from equations (1) and (2).

Fryze power theory was further developed in the works of Ukrainian [14-18] foreign specialists [1922] and, but without proposing practical methods for its application. Moreover, in [19], it is noted that the fundamental disadvantage of Fryze power theory is the impossibility of decomposition of the instantaneous nonsinusoidal current into active and reactive components.

Thus, to calculate the reactive power using Fryze power theory, it is necessary to substantiate the method of isolating the reactive component of nonsinusoidal current and work out an formula for its calculation.

The purpose of the study is to work out an expression for calculating the reactive power of induction motors depending on the control parameters of semiconductor converters. The task is to decompose non-sinusoidal current into active and reactive components by computer simulation.

\section{TECHNIQUE FOR DETERMINING THE REACTIVE POWER OF INDUCTION MOTORS}

The goal set is solved in two stages:

1) making a computer model of the motor with a semiconductor voltage converter;

2) conducting research of the dependence of the reactive current on control parameters of the converter using the computer model.

As a model of an induction motor, it is advisable to use the classic $L$-shaped circuit, the parameters of which are determined from reference data, in particular, the active resistance in the magnetic circuit is calculated through the power factor of idle speed. To isolate the reactive component from the total current, we make a model (Fig. 1).

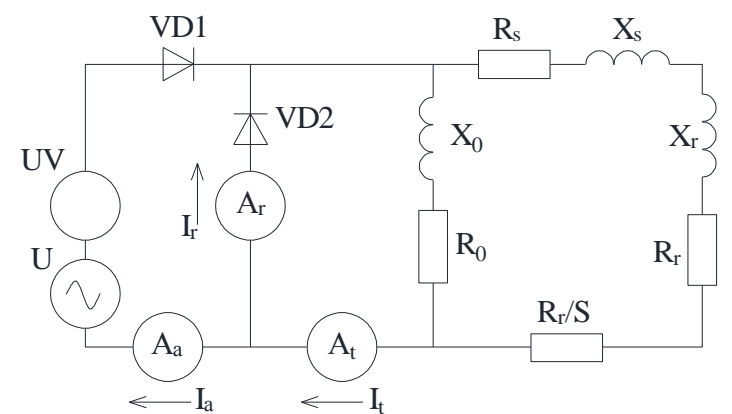

Figure 1. Model of asynchronous electric drive with decomposition of converter current components

The model contains a voltage source $U$ with a voltage converter UV, to the output of which a diode VD1 is connected to select a positive half-wave voltage. At the input of the equivalent circuit, the reverse-biased diode VD2 is placed to select the reactive current component. The model includes ammeters for measuring the instantaneous values of active $I_{a}$, reactive $I_{r}$ and total $I_{t}$ currents.

The selection of the reactive component of the current is as follows. When the positive half-wave voltage from the converter reaches zero, the diode VD1 is switched off, i.e., the equivalent circuit is disconnected from the converter. At the same time, the diode VD2 is switched on because the positive charge from the self-induction EMF of the equivalent circuit appears on its anode and the current from the magnetic field energy flows through it. Since the current source is the EMF of self-induction and the current does not return to the voltage source, it is called a reactive current. Hereinafter, this process will be illustrated in detail using current oscillograph records obtained during the experiment.

The method of determining the reactive current consists of two steps:

1) calculating the dependence of the total current on the control parameter of the converter;

2) determining the reactive component of the total current.

For practical purposes, these dependences must be "tied up" to the basic parameter of the motor, which is specified in manuals or technical data sheets of sinusoidal motors. As a basic parameter, it is advisable to take the nominal value of the idle current, in view of the following considerations.

The idle current (by 93-97\%) is reactive and, as can be seen in the L-shaped circuit (Fig. 1), the current of the magnetizing branch $R_{0}-X_{0}$ depends only on the control parameter of the converter. The operating current also depends on the resistance $R_{r} / S$, which simulates the mechanical load on the rotor shaft, where $S$ is the motor slip. To take into account the reactive dissipated current, it is necessary to perform simulations at the nominal motor slip. 
Further, it is necessary to take generalizing parameters that do not depend on engine power and combine them in the expression with the basic parameter. As generalizing parameters, we accept:

1) current transfer ratio of the converter $K_{t}$, as the ratio of the idle current $I_{i d}$ of the motor when powered from the converter to the rated idle current $I_{i d}$ of the sinusoidal power supply;

2) reactive current ratio $K_{r}$, as the ratio of the reactive component $I_{r}$, to the total motor current when powered by the converter.

Next, using computer simulation, we determine the dependences of $K_{t}$ and $K_{r}$ on the control parameters of the converter, followed by their approximation by the method of least squares. After determining the specified ratios, the expression for calculating the reactive power for a given average value of the control parameter has the form

$$
Q_{L}=\left(x_{0}+x_{\sigma}\right) K_{t} K_{r} I_{i d}^{2} .
$$

Thus, expression (3) combines the idle current of the motor with sinusoidal power supply and the coefficients, which depend on the control parameters of the voltage converters, i.e., the firing angle of the thyristors in case of phase triggering or the relative conductivity interval of the transistors in case of pulse-width control. As an example of the use of expression (3), we calculate the reactive power for an induction motor with a thyristor power controller (TPC). The equation of electrical equilibrium of the equivalent circuit on the conduction interval of the thyristor has the form

$U_{m} \sin (\omega t+\alpha)=i R_{s c}+L_{s c} \frac{d i}{d t}$

where $\alpha$ is the firing angle of the TPC; $R_{s c}, L_{s c}$ is the active resistance and inductance of the equivalent circuit.

The instantaneous value of the total current, as the sum of the periodic and aperiodic components of the transient process of connecting the equivalent circuit to the source of sinusoidal voltage, with the trigger phase equal to the firing angle, has the following form

$$
i=\frac{U_{m}}{Z}\left[\sin (\omega t-\phi)-\sin (\alpha-\phi) \cdot e^{-(\omega t-\alpha) \operatorname{ctg} \phi}\right],
$$

where $Z=\sqrt{R_{s c}^{2}+\left(\omega L_{s c}\right)^{2}}$ is the impedance module of the equivalent circuit; $\phi=\operatorname{arctg}\left(\omega L_{s c} / R_{s c}\right)$ is the angle of shift of the current graph from the voltage graph at sinusoidal power supply.

In expression (5) the value $U_{m} / Z=I_{\text {m.id.s }}$ is the range of the rated value of the total idle current at sinusoidal power supply. So, the effective value of expression (5) is obtained by using integration on the conduction interval of the thyristor, which can be represented as $I_{i d}^{T V C}=K_{T V C} I_{i d}^{S}$, where $K_{T V C}$ is the current transfer coefficient of the TPC, which is equal to the expression in square brackets of formula (5). For clarity of determining $K_{T V C}$, we will construct the graph of instantaneous total current for expression (5) (Fig. 2). On the graph, the following values are marked: $\alpha, \beta, \lambda$, are respectively: firing angle, extinction angle and conduction angle of the thyristor, $i_{a}$ is the aperiodic current component, $i_{p}$ is the periodic current component, $i_{t}$ is the graph of the transient current based on equation (5).

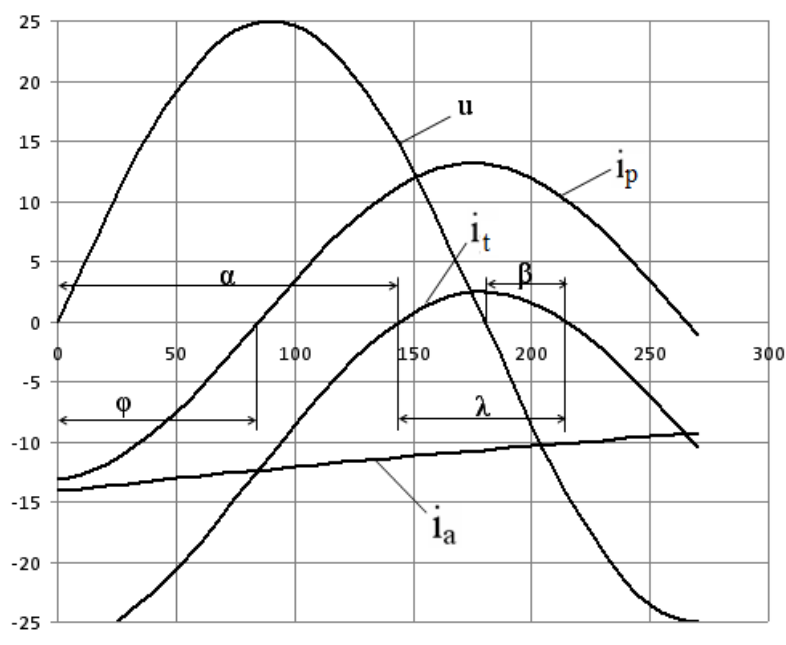

Figure 2. Graphs of the components of the transient current in the thyristor conductivity range

After performing the corresponding mathematical operations with expression (5), to determine the effective value of the current, we obtain the current transfer ratio for the TPC:

$$
\begin{aligned}
& K_{T V C}=\left\{\frac{1}{2 \pi}\left[\lambda-\frac{\sin 2(\alpha+\lambda-\phi)}{2}+\frac{\sin 2(\alpha-\phi)}{2}\right]+\right. \\
& +\frac{2 \sin (\alpha-\phi)}{1+\operatorname{ctg}^{2} \phi_{c}}\left\{e^{-\lambda \cdot \operatorname{ctg} \phi}[\operatorname{ctg} \phi \sin (\alpha+\lambda-\phi)+\right. \\
& +\cos (\alpha+\lambda-\phi)]-\operatorname{ctg} \phi \cdot \sin (\alpha-\phi)-\cos (\alpha-\phi)\}+ \\
& \left.+\frac{\sin ^{2}(\alpha-\phi)}{2 \operatorname{ctg} \phi}\left(1-e^{-2 \lambda \cdot \operatorname{ctg} \phi}\right)\right\}^{1 / 2} .
\end{aligned}
$$

In expression (6), the conduction angle, according to Fig. 2 , is equal to $\lambda=\pi-\alpha+\beta$, where $\beta$ is the unknown extinction angle of thyristors relative to the trailing edge of the voltage sinusoid. Its dependence on the firing angle is obtained by simulation followed by approximation by an analytical formula.

To determine the extinction angle of the thyristor, we make a model of the software package SimPowerSystem (Fig. 3), which works as follows. 


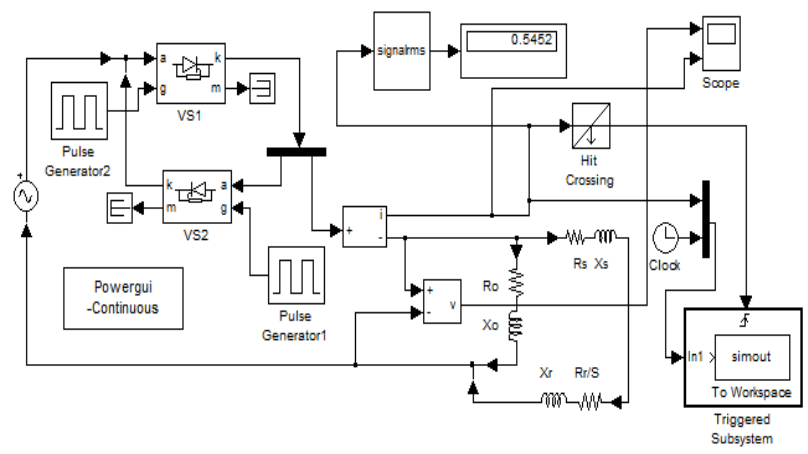

Figure 3. Model for determining the extinction angle of the thyristor

Trigger pulses for thyristors form the Pulse Generator block, thus the size of the firing angle is set by duration of the phase delay (Phase Delay) of the generator (Pulse Generator). To control the reaching of the zero value of the current by the trailing edge, the Hit Crossing block is used. At the same moment, it generates a trigger pulse to run the Triggered Subsystem block with the Simout block, to input the current time to the Workspace block. The current time is counted down by the Clock block. Measurement of the extinction angle of the thyristors occurs when the trailing edge reaches the zero value of the current, i.e. $\beta=t-0.01 \mathrm{~s}$.

It is worth noting that the library of the package SimPowerSystam has a block model of an induction motor, based on differential equations. However, as subsequent computer experiments have shown, after the transition process is completed, voltage and current waveforms are identical to those of the model with the equivalent circuit. The latter is convenient because it immediately achieves a steady state and requires less time for modeling, which is important for a significant number of experiments.

As a result of modeling, the dependence $\beta=f(\alpha)$ is received, with its subsequent approximation by the method of least squares

$$
\beta=0.915 \cdot \pi-0.916 \cdot \alpha=2.875-0.916 \cdot \alpha \text {. }
$$

Thus, the value of the current transfer ratio for the TPC at a given firing angle of the thyristors is determined by the substitution (7) in (6). We proceed to determining the reactive current coefficient by simulation. The scheme of the model is shown in Fig. 4 . Fig. 5 shows the voltage waveforms and current components obtained using the model.

As can be seen from the oscillogram in Fig. $5 b$, the current flows through the reverse-biased diode during the interval of zero voltage from the converter, i.e., the current source is the self-induction EMF from the inductance of the equivalent circuit, therefore, it is the reactive current. The oscillogram in Fig. $5 c$ shows that the current from the converter coincides in phase with the voltage, therefore, it is the active current.

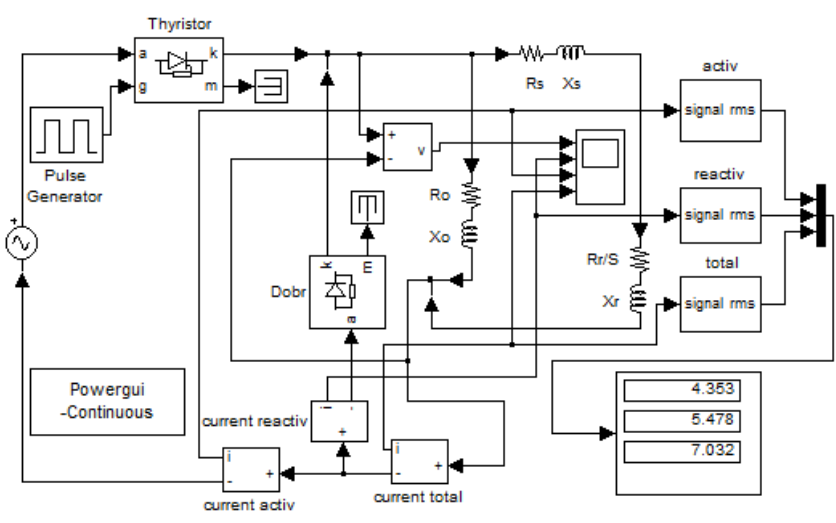

Figure 4. Model for determining the reactive current of an asynchronous electric drive with a TPC

Thus, the model can help obtain the dependence of the reactive component of the current on the firing angle of the thyristors.

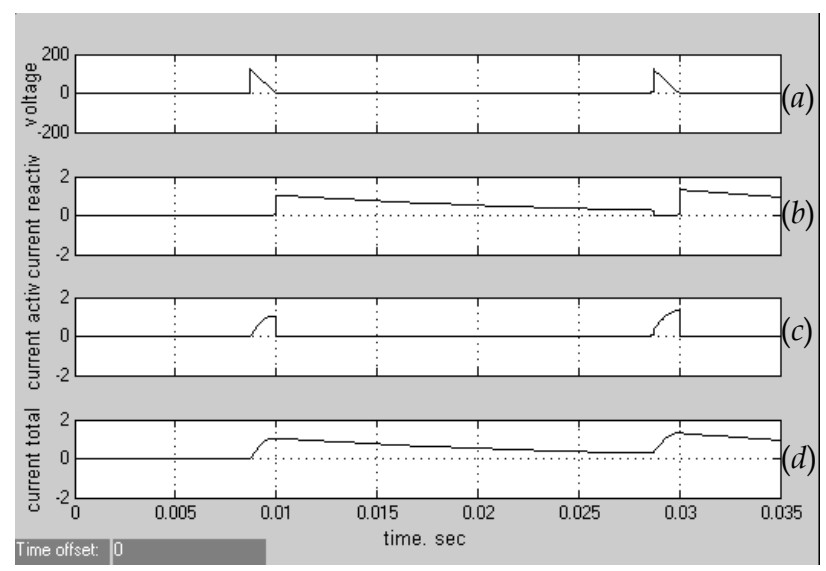

Figure 5. Voltage waveforms and current components: (a) - stator winding voltage; $(b)$ - reverse-biased diode current (reactive); (c) - mains current (active); $(d)$ - total idle current

To verify the generality of the coefficients $K_{t}$ and $K_{r}$ simulation was performed for three engine powers: $3.5 \mathrm{~kW} ; 7.5 \mathrm{~kW} ; 11 \mathrm{~kW}$, which are used in electric drives of water pumps and fans. The results of calculating the coefficients $K_{t}$ and $K_{r}$ showed their practical independence from engine power. As a result of the approximation of the dependence $K_{r}=f(\alpha)$ by the method of least squares, the formula for determining the reactive current coefficient of an asynchronous electric drive with TPC has been obtained

$$
K_{r}=0.675+0.1 \alpha .
$$

Thus, to calculate the reactive power of an induction motor with TPC, values (6) and (8) are substituted into equation (3), which is used to calculate the capacity of the compensating capacitors. It can also be calculated through the equality of the effective values of the reactive energies of the stator winding and capacitors, i.e., 
$W_{L}=L I_{r}^{2}, W_{C}=C U_{T V C}^{2}$,

where $I_{r}$ is the effective value of the reactive current, determined by the formula $I_{r}=K_{T V C}(0.675+$ $+0.1 a) I_{i d}^{S} ; U_{T V C}$ is the output voltage of the TPC, determined by the formula

$U_{T V C}=\frac{U_{m}}{\sqrt{2 \pi}} \sqrt{\lambda-\frac{\sin 2(\alpha+\lambda)}{2}+\frac{\sin 2 \alpha}{2}}$.

If the firing angle of the TPC changes within a certain range, then all equations should take its average value. The output voltage of the TPC can also be determined similarly to the reactive current, i.e., through $K_{r}$ because the current is generated by the output voltage.

Similar calculations can be performed for the case of powering induction motors by a transistor voltage converter with pulse-width modulation.

\section{CONCLUSIONS}

A technique for determining the reactive power of induction motors when powered by semiconductor converters is developed. The implementation of the technique resulted in the following. The dependences of the total current and its reactive component on the control parameter of the converter are determined by computer simulation with their subsequent approximation by the method of least squares. The square of the reactive current is multiplied by the sum of the inductive resistances of the magnetization and scattering of the replacement circuit of the induction motor.

As an example of using the technique, the calculation of reactive power for an induction motor with a thyristor power converter is performed. Similarly, it is possible to obtain empirical formulas for transistor power converters with pulse-width modulation.

The scientific novelty of the results is in the further development of Fryze power theory in the direction of decomposition of non-sinusoidal current components in electric circuits with nonlinear loading, using computer models and a reverse-biased diode.

\section{DISCLOSURE STATEMENT}

No potential conflict of interest was reported by the author(s).

\section{REFERENCES}

1. Jeon, S.J. (2020). Passive-component-based reactive power compensation in a non-sinusoidal multi-line system. Electrical Engineering, 102, 1567-1577. https://doi. org/10.1007/s00202-020-00979-8
2. Andrei, H., Andrei, P.C., Cazacu, E., \& Stanculescu, M. (2017). Fundamentals of reactive power in AC power systems. In N. Mahdavi Tabatabaei, A. Jafari Aghbolaghi, N. Bizon, \& F. Blaabjerg (Eds), Reactive Power Control in AC Power Systems (pp. 49-115). Springer. https:/ / doi.org/ 10.1007/978-3-319-51118-4_2

3. Chica Leal, A.D.J., Trujillo Rodríguez, C.L., \& Santamaria, F. (2020). Comparative of power calculation methods for single-phase systems under sinusoidal and non-sinusoidal operation. Energies, 13(17), 4322. https:// doi.org/10.3390/en13174322

4. Qawaqzeh, M.Z., Bialobrzheskyi, O., \& Zagirnyak, M. (2019). Identification of distribution features of the instantaneous power components of the electric energy of the circuit with polyharmonic current. Eastern-European Journal of Enterprise Technologies, 2(8-98), 6-13. https:// doi.org/110.15587/1729-4061.2019.160513

5. Bialobrzeski, O.V., \& Rodkin, D.I. (2019). Alternative indicators of power of electric energy in a singlephase circuit with polyharmonic current and voltage. Electrical Engineering \& Electromechanics, 1, 35-40. https:/ / doi.org/10.20998/2074-272X.2019.1.06

6. Wang, J., \& Duan, C. (2010). Equivalent power spectrum analysis method for feature extraction. In 2010 International Conference on Measuring Technology and Mechatronics Automation (Vol. 2, pp. 120-123). IEEE. https:// doi.org/10.1109/ICMTMA.2010.222

7. Emanuel, A.E. (2010). Power definitions and the physical mechanism of power flow. John Wiley \& Sons. https:// doi.org/10.1002/9780470667149

8. Jeltsema, D. (2015). Budeanu's concept of reactive and distortion power revisited. In 2015 International School on Nonsinusoidal Currents and Compensation (ISNCC) (pp. 1-6). IEEE. https:// doi.org/10.1109/ISNCC.2015.7174697

9. Willems, J.L. (2011). Budeanu's reactive power and related concepts revisited. IEEE Transactions on Instrumentation and Measurement, 60(4), 1182-1186. https:// doi.org/ 10.1109/TIM.2010.2090704

10. Zagirnyak, M., Korenkova, T., \& Kovalchuk, V. (2014). Estimation of electromechanical systems power controllability according to instantaneous power components. In 2014 IEEE International Conference on Intelligent Energy and Power Systems (IEPS) (pp. 266-272). IEEE. https://doi.org/10.1109/IEPS.2014.6874192

11. Bialobrzheskyi, O., Rod'kin, D., \& Gladyr, A. (2018). Power components of electric energy for technical and commercial electricity metering. Naukovyi Visnyk Natsionalnoho Hirnychoho Universytetu, 2, 70-79. https:// doi.org/10.29202/nvngu/2018-2/10

12. Shurub, Y.V., Vasilenkov, V.Y., \& Tsitsyurskiy, Y.L. (2018). Investigation of properties of combined scheme of single-phase switching of induction electric drive of pumping plants. Technical Electrodynamics, 2018(6), 50-53. https:/ /doi.org/10.15407/techned2018.06.050

13. Malyar, V., Hamola, O., \& Maday, V. (2016). Calculation of capacitors for starting up a three-phase asynchronous motor fed by single-phase power supply. In 2016 17th International Conference Computational Problems of Electrical Engineering (CPEE) (pp. 1-4). IEEE. https://doi. org/10.1109/CPEE.2016.7738735 
14. Kovalova, Y., Kovalova, V., \& Feteev, V. (2019). Asynchronous phase rotor motor in reactive power compensator mode. Lighting Engineering \& Power Engineering, 2(55), 63-67. https://doi.org/10.33042/2079-424X-2019-255-63-67

15. Bondar, O., Kostin, M., Mukha, A., Sheikina, O., \& Levytska, S. (2019). Fryze reactive power of trams in effective stochastic recuperation processes. MATEC Web of Conferences, 294, 01006. https://doi.org/10.1051/matec conf/201929401006

16. Tugay, D., Zhemerov, G., Korneliuk, S., \& Kotelevets, S. (2019). Three theoremes of the instantaneous power theory. In 2019 IEEE 2nd Ukraine Conference on Electrical and Computer Engineering (UKRCON) (pp. 289294). IEEE. https://doi.org/10.1109/UKRCON.2019.887 9901

17. Batygin, Y., Shinderuk, S., Chaplygin, E., Gavrilova, T., \& Bespalov, K. (2020). Suggestion, calculations, practical approbation of the resonant amplifier of the reactive electrical power. Lighting Engineering $\mathcal{E}$ Power Engineering, 2(58), 65-72. https://doi.org/10.33042/2079424X-2020-2-58-20-27

18. Zhemerov, G.G., \& Tugay, D.V. (2015). Physical meaning of the «Reactive Power» concept applied to three-phase energy supply systems with non-linear load. Electrical Engineering E Electromechanics, 6, 36-42. https:/ / doi.org/10.20998/2074-272X.2015.6.06

19. Morsi, W.G., \& El-Hawary, M.E. (2007). Defining power components in nonsinusoidal unbalanced polyphase systems: the issues. IEEE Transactions on Power Delivery, 22(4), 2428-2438. https://doi.org/10.1109/TPW RD.2007.905344

20. Vieira, D., Shayani, R.A., \& de Oliveira, M.A.G. (2017). Reactive power billing under nonsinusoidal conditions for low-voltage systems. IEEE Transactions on Instrumentation and Measurement, 66(8), 2004-2011. https:// doi.org/10.1109/TIM.2017.2673058

21. dos Santos, N.G.F., Hey, H.L., Zientarski, J.R.R., \& da Silva Martins, M.L. (2020). Piecewise Fryze power theory analysis applied to PWM DC-DC converters. IET Power Electronics, 13(10), 2029-2038. https://doi.org/10. 1049/iet-pel.2019.1053

22. Wang, D., Zhang, L., Wang, C., Liu, S., \& Liu, Q. (2019). A harmonic detection strategy based on FBD power theory. In 2019 IEEE PES Asia-Pacific Power and Energy Engineering Conference (APPEEC) (pp. 1-5). IEEE. https:// doi.org/10.1109/APPEEC45492.2019.8994402

\title{
Реактивна потужність асинхронних електроприводів з напівпровідниковими перетворювачами напруги
}

\author{
Юлія Ковальова, Віктор Ковальов, Ірина Щербак
}

\begin{abstract}
Анотація. Метою статті є отримання співвідношення для визначення реактивної потужності асинхронних двигунів при їх живленні від напівпровідникових перетворювачів напруги. Задача полягає у визначенні залежності реактивної потужності від параметрів керування перетворювачами. Як метод дослідження було обрано комп'ютерне моделювання електропривода на основі теорії потужності Фризе для несинусоїдних струмів. В результаті отримано вираз для розрахунку реактивної потужності, який враховує номінальний струм неробочого ходу двигуна при синусоїдному живленні та тип перетворювача за рахунок уведених спеціальних коефіцієнтів. Числові значення останніх в залежності від параметру керування отримуються на комп'ютерних моделях з їх подальшою апроксимацією. У якості наукової новизни, набула подальшого розвитку теорія потужності Фризе в напрямку декомпозиції складових несинусоӥдного струму з використанням комп'ютерних моделей. Практична значимість полягає в отриманні виразу для визначення реактивної потужності асинхронного електропривода 3 тиристорним перетворювачем напруги, на основі якого розраховується ємність компенсуючих конденсаторів для підвищення його енергоефективності.
\end{abstract}

Ключові слова: асинхронний двигун, напівпровідниковий перетворювач, реактивна потужність.

\section{NOTES ON CONTRIBUTORS}

\section{Yuliia Kovalova}

kovalova.jv@gmail.com

Victor Kovalov

kovalov1952@gmail.com

Irina Shcherbak ie.shcherbak@gmail.com
Ph.D., Associate Professor

Department of Urban Power Supply Systems and Power Consumption

O. M. Beketov National University of Urban Economy in Kharkiv, Kharkiv, Ukraine

(iD) https://orcid.org/0000-0002-2931-9176

p https://publons.com/researcher/Q-7927-2018

SC https:// scopus.com/authid/detail.uri?authorId=57210624425

Ph.D., Associate Professor

Department of Automated Electromechanical Systems

National Technical University "Kharkiv Polytechnic Institute", Kharkiv, Ukraine

(iD) https:// orcid.org/0000-0001-5817-8790

Ph.D., Assistant

Department of Urban Power Supply Systems and Power Consumption

O. M. Beketov National University of Urban Economy in Kharkiv, Kharkiv, Ukraine

(iD) https:// orcid.org/0000-0003-1211-4665 